\title{
METAVIR Fibrosis Score
}

National Cancer Institute

\section{Source}

National Cancer Institute. METAVIR Fibrosis Score. NCI Thesaurus. Code C119572.

A scoring system for liver fibrosis developed by Bedossa and Poynard (Bedossa P, Poynard T. An algorithm for the grading of activity in chronic hepatitis C. The METAVIR Cooperative Study Group. Hepatology. 1996 Aug; 24(2):289-93.), based on a 5 category scale. 